\title{
AUTHORING PARTICIPATION
}

by Irina Papazu

Samsø, Denmark's Renewable Energy Island since 1997, is world-renowned for being self-sufficient in renewable energy and for having achieved energy self-sufficiency and $\mathrm{CO}_{2}$ neutrality through successful processes of public participation. In this article I seek to show how these processes of public participation so central to the Renewable Energy Island project can be better understood as instances of material participation motivated first and foremost by a concern for the future of the island as a 'liveable' community; a community in which jobs and institutions are not constantly threatening to disappear. By turning to material participation, a concept inspired by Noortje Marres and Jennifer Gabrys, the efforts put into Samsø's energy transformation by the islanders are given specificity. On Samsø, the islanders' participation was not an add-on to the project, it was an indispensable resource in itself. Building on extensive fieldwork I analyse how the islanders came to invest their time and resources in the Renewable Energy Island project, highlighting how, by materializing energy in concrete, local projects, energy and climate change-related projects can gain community-strengthening potentialities reaching beyond goals of energy self-sufficiency.

Keywords: Author: 


\section{N}

NORDIC JOURNAL

of Science and Technology Studies

\section{Introduction}

Samsø, a rural island home to three thousand seven hundred inhabitants, is Denmark's Renewable Energy Island (REI). The island is world-renowned for being self-sufficient in renewable energy from wind, sun and biomass'. The islanders' combined carbon footprint is 'negative' due to Samsø's export of surplus wind electricity to the Danish mainland. However impressive the technological transformation of the island's energy systems, the project was never approached as a purely or even primarily technical challenge. When a group of islanders handed in their application to the Danish Ministry of Energy to start work on becoming Denmark's Renewable Energy Island over a ten-year period from 1997 to 2007, the islanders' main objective was not to 'go green', to lower Samsø's CO2 emissions or to make Samsø a famous demonstration site for Danish renewable technologies, as was the Ministry's main objective. The islanders' main goal was to secure the survival of the island community. In the words of the project director Søren Hermansen, "We wanted to establish a platform of citizens capable of taking responsibility for their own community. It matters less whether the end product is windmills or a new Internet connection or a new ferry... We had to learn to cooperate" (interview, Nov 2013).

While the world has primarily turned its attention to the 'green' dimension of Samsø's transformation ${ }^{2}$, the locally defined objectives that engaged the islanders had to do with making the island community viable. In order to strengthen the community's viability - to create jobs, to cooperate on new projects, to revitalize local businesses and keep people from leaving the island - every islander had to be a participant in the island's transformation. When participation is understood in this manner, it cannot be limited to a question of acceptance of new technologies or regarded as an issue of increasing the robustness and legitimacy of actions and decisions. We have to revisit our understanding and widen the scope of participation; this is the first contribution of this article.

When the islanders participate and get engaged in renewable energy (RE) projects, they enact Samsø's new renewable reality through their everyday actions, in working groups or at home. Sometimes they join public meetings arranged by the project developers (who were also locals), but this is not where the real work of participation is done, I will argue. To provide an example, during the REI project years on Samsø, when working on altering the island's heating systems, if a village could not find enough people to form a citizen group, the village would be passed over

\footnotetext{
Eleven megawatt (MW) wind power were needed to make Samsø selfsufficient with electricity. These are produced by eleven $1 \mathrm{MW}$ onshore wind turbines erected in 1999-2000 owned by a windmill cooperative and by local individual owners. In 2002 ten 2,3 MW offshore windmills were erected - for a brief period the largest offshore windfarm in the world - to compensate for the $\mathrm{CO}_{2}$ emissions from the islanders' means of transportation: tractors, cars, buses and ferries. Sixty percent of the island homes are supplied with district heating and forty percent with individual heating systems, e.g. heat pumps and solar collectors. A few have kept their non-RE systems (Hermansen et al 2007). 2 See. e.g. the New York Times (Taglibue 2009, Cardwell 2015) Time Magazine (Walsh 2009) and The Guardian (Bonne 2008, Kingsley 2012).
}

and would most likely not get their own district heating station, as the villagers themselves had to put in the bulk of the actual work involved in the projects.

This article focuses on participation as a resource, as work, as material actions, and on how, on Samsø, these processes of participation have become part of what makes the Danish Renewable Energy Island famous. Through the islanders' concrete down-toearth actions, renewable energy has been reframed and rescaled as being about social change and community making rather than about efficiency calculations, markets, national and European energy policies and $\mathrm{CO}_{2}$ credits. The second contribution of this article is to offer an empirically grounded new perspective on community-based RE transformations, a field that is inspiring still more people, on Samsø reflected in the three to five thousand 'energy tourists' who travel to the island from all over the world each year to learn about what Samsø did.

This paper builds on an extensive fieldwork conducted on Samsø where I lived for six months in 2013 and 2014. From my office space at Samsø Energy Academy (an organization with ten employees welcoming visitors, giving presentations about the REI project, and initiating new RE projects on Samsø) I did participant observation and had daily informal conversations. I carried out some thirty interviews with central island actors and Energy Academy employees and ploughed through old and new reports, newspaper articles and books about Samsø and the REI project. For this article, I draw on all these data sources. The fieldwork led me all around the island trying to develop an understanding of the processes through which Sams $\varnothing$ became Denmark's REI and of what this title means today as Sams $\varnothing$ continues to assert this status, among other things through new RE projects and through dissemination of the experiences.

It is important to note that as the REI project unfolded from 1997 to 2007, my data material is conditioned by the limitations of people's memories and the less than systematic filing of the documents related to the RE projects. Details of conflicts, negotiations, even controversy have a tendency, I discovered, to recede into the background as projects are successfully completed and the RE technologies have become part of the Samsø landscape. As a consequence, the described events may come across as less dynamic than one would expect for such a comprehensive undertaking, but I have attempted throughout to provide as much detail as possible.

The article proceeds as follows: After taking a closer look at the Samsø community, the article proceeds to discuss participation theory and the possibilities offered by Science and Technology Studies (STS) for reframing participation. Especially Noortje Marres' notion of material participation and Jennifer Gabrys' 'cosmopolitics of energy' will be contrasted with more procedurally focused perspectives on public participation, shifting the emphasis from knowledge and democracy to materially grounded, informal, 


\section{N}

NORDIC JOURNAL

of Science and Technology Studies

practical actions framed by the energy project. The analysis will give examples from my fieldwork of how this specific form of participation played out in practice on Samsø and will detail the significance of the inclusiveness of the REI project - its ability to connect registers (environmental, economic, social) commonly understood as antithetical - for the realisation of the project.

\section{"We're all in the same boat"}

Samsø, being Denmark's Renewable Energy Island, is popularly known to be energy self-sufficient. In fact, however, Samsø has not exactly gone 'off-grid' and it is not self-sufficient in the strict sense of the word. The island is connected to the Danish mainland through a cable essential to the functioning of the island's electricity system (Karnøe 2013). Without the cable, the island would not be able to send its surplus wind electricity into the Danish electricity grid, and in the absence of large-scale RE alternatives to wind electricity on the island, the connection to the mainland allows the islanders to also "make coffee on calm days when the wind isn't blowing" (interview, islander, Nov 2013).

Self-sufficiency and localism on Samsø, then, are not about going off-grid, and it certainly is not about insularity. On the contrary, the aim of the REI project has to a large extent been to strengthen the island's ties to the mainland; to become less peripheral in a country where centralization is an ever bigger threat to small communities facing depopulation, unemployment and the closure of vital local institutions. As the chief executive of Samsø Municipality formulated it in a seminar, "we can't exist as an island community if we're not completely entangled in Danish society. Instead of breaking loose, we need to strengthen our connections. If for example we need to raise DKK two hundred and fifty million [EUR thirty-five million] for a new ferry, how would we raise that kind of money if we couldn't get support from the outside?" On Samsø there is a strong sense of insularity, to which we shall shortly return. Paradoxically, the REI project that has made Samsø virtually energy self-sufficient has also brought Samsø closer to the rest of Denmark and the world by putting Samsø on the map, thus making Samsø relevant as an interesting case, as a partner in projects, as a place to seek knowledge and inspiration. This is localism and self-sufficiency with the purpose of overcoming the confinement to the local.

When the director of Samsø's Energy Academy Søren Hermansen, a Time Magazine 'Hero of the Environment' in 2008 and figurehead of the REI project, gives his talks about Samsø, the stories about windmills and district heating plants are not the actual matter of the story, he tells me (interview, Nov 2013). What is at the heart of the story is the life that unfolds around those technological arrangements. And that story, 'the real story', is about how you take control of your community's development. "Through those actions we carried out ten years ago, we have become a less vulnerable society", he claims.

Talking to the islanders, the reality of living on an island and the sense of vulnerability that comes with it figure prominently. "I live on an island, so there is a physical thing about this", a local politician stated (interview, Oct 2013), referring to the island condition as a physical limitation. Hermansen, the director, contrarily, tends to frame living on an island as a resource and a condition that makes collaboration easier. He will refer to the islanders as being gathered around a campfire, "connecting to the same idea of the commons" and compelled to manage this commons together. In framing the island as a commons he evokes the well-known story often related to anthropogenic climate change, namely 'the tragedy of the commons' (Hardin, 1968), denoting a situation in which individuals, acting independently and rationally according to their self-interest, end up depleting the common resource. With Samsø a well-defined common resource, Hermansen points out the necessity of finding community-based rather than individual solutions.

Being a clearly demarcated community comes with its strengths - "Samsø being so small makes it easy to gather the troops" (local politician, Oct 2013) - and weaknesses. In my interviews, many islanders mentioned that people have a strong sense of being 'in the same boat': "We probably stick together more because we're an island... We're surrounded by water, and that humbles you. Everyone knows we're all in the same boat" (interview, islander, Oct 2013). Life on an island compels you to get engaged, you feel obligated to contribute, because "everyone must fight for the survival of the community" (farmer, interview, May 2014). There are two sides to the coin. On the one hand, you are a part of a close-knit community. On the other, as the former folk high school principal remarked, "you enter an uncertain world when you move to Samsø" (interview, Nov 2013).

This shared sense of vulnerability is connected with the steady loss of jobs and closure of institutions, the demographic development working against Samsø with ever more elderly people and still fewer families with children, the sense of being at the mercy of the national politicians' decisions covering everything from ferry ticket prices to strategies for the development of the peripheral-rural areas. In the nineties, it was the precariousness of island life that created the need to look for alternatives to prevent the island from "slowly bleeding to death", as the head of the technical and environmental administration in Samsø Municipality graphically put it (interview, Oct 2013).

In fact, the consensus around the idea of the vulnerable island community is so strong that Hermansen, moderator of an election debate preceding the 2013 municipal election, exclaimed in his introduction of the politicians: "We're here to discuss Samsø's future, and that makes me wonder why we have eight parties running when we're all working towards the same goal" (field 


\section{$\$$}

NORDIC JOURNAL

of Science and Technology Studies

notes, Nov 2013). While there is still politics on Samsø and there may be diverging views on the island's future directions, there is little disagreement as to the importance of hard work in order to preserve Samsø as a viable community. This is the common project, and this is where the REI project came as a welcome opportunity when in 1997 the Danish Ministry of Energy issued a competition to find an island willing to commit to a full transition to RE technologies over a ten-year period. It is the central contention of this article that had it not been for the practical and hard work put into the project by the islanders, the goals of the REI project would not have been accomplished, and, further, that this type of work can be characterized as public participation of a specific kind. It is to this discussion of participation in theory and in practice that we now turn.

\section{Public participation in theory and practice}

Within and in the close vicinity of STS research public participation takes on many faces (Antonsen, Ask and Karlstrøm 2014). I will comment upon three of these 'faces' in order to make clear the ways in which these do not adequately cover the empirical reality I encountered on Samsø. This will lead me to, in the following section, propose an alternative approach to participation, still drawing on the field of STS.

A first approach is centered upon debates about knowledge and expertise and fora of public participation. Classic settings are the consensus conference (Bruun Jensen 2005, Blok 2007), the roundtable (Felt \& Fochler 2009) or a similar temporary arrangement set in some kind of artificial environment, a site designed specifically for the participation event, in which citizens and scientists meet to discuss complex themes typically relating to the governance of science and technology in society (see also Cammaerts \& Carpentier 2005). The purpose of these studies tends to be to "criticize particular engagement activities while... expressing a commitment to a wider principle of 'democratization'" (Irwin et al. 2013: 119)3. This democratic endeavour, the notion that other types of knowledge and expertise besides those of established science deserve a voice, is central to the branch of STS often referred to as Public Engagement with Science (PES).

Another academic genre from which we can take clues about public participation and which is similarly concerned with democratizing scientific debate is controversy studies. These typically deal with the participation or engagement of the public in conflict situations. In these studies, too, there is a tendency to portray the public as 'lay persons' who find themselves implicated in, but outsiders to, issues defined and demarcated by scientific experts (see e.g. Wynne 1992, Epstein 1995, Suryanarayanan 2013).

A third approach to public participation includes actor-network theory (ANT) with its focus on the enrolment of actors, and the sociology of innovation more broadly. In the classic ANT studies, the notion that actors must be enrolled in networks implies that if actors are not successfully enrolled, if their interests are not

3 Further, there are other, even more critically oriented contributions to partic ipation research which take an evaluative or typologizing approach criticizing top-down techniques of public involvement, formulating criteria of success to be met by participation processes and identifying ideal typical participation mechanisms (see e.g. Lawrence 2006, Stirling 2008, Rowe \& Frewer 2000). brought into alignment with the goals of the network, the network will fail to form (e.g. Callon 1986). A similar logic pertains to many theories of technological innovation, among others domestication theory, which posits that when new technologies are introduced, they must be accepted and adapted by their users to become part of everyday life (see. e.g. Sørensen 1994). This joint focus on acceptance and compliance, and the logic that there are spokespeople (ANT) or producers (innovation) who push for a certain development, attempting to subordinate actors or users to their interests, is an underlying current in this tradition.

The Samsø case departs from the reviewed literature in a number of ways. Firstly, these studies place debates over science and technology at the heart of STS-oriented participation research. On Samsø, while RE technologies certainly provide the material setting for the local projects, the technologies are means rather than goals. They are the reason to get organized, they are the subjects of discussion and the objects of collaboration. Still, it is the collaboration that is praised as the end product. To repeat director Hermansen's words: "We wanted to establish a platform of citizens capable of taking responsibility for their own community. It matters less whether the end product is windmills or a new Internet connection or a new ferry". The RE technologies were not dispensable, as such, but in line with the director's words, they may have been replaceable; they were what the islanders acted through, rather than towards. ${ }^{4}$

Secondly, there is a focus on knowledge and expertise in the literature on public participation which does not apply to the Samsø case. The literature tends to foreground knowledge either as an impediment to public involvement - whether citizens can be involved in problems obscure to them (Felt \& Fochler 2009; on the 'knowledge deficit model' see e.g Wynne 1991) or as an argument for involvement (citizens contributing valuable local knowledge) (Kastens \& Newig 2008, Wynne 1992). On Samsø, everyone involved in the REl project, apart from an engineer from the mainland engaged in the early stages of the project, was a local 'lay citizen'. At the onset of the project, no one was an expert. Knowledge was not a key resource; instead, the willingness to educate oneself and acquire new skills became an important prerequisite for certain actors' commitment.

4 for a comparable analysis underlining how technological artifacts can be used to pursue connections to wider goals, see Dunbar-Hester 2014 


\section{N}

NORDIC JOURNAL

of Science and Technology Studies

Lastly, a fundamental dichotomy frequently encountered in the participation literature is that of substantive vis-à-vis instrumental arguments for citizen involvement (Hoff 2015, Stirling 2008). Instrumental arguments for citizen participation focus on how participation can improve the implementation or realisation of a given decision, technology or project. Accept, confidence and ownership are key concepts. The logic is that by involving the public, opposition is avoided. Substantive arguments for public participation, on the other hand, focus on the outcome, claiming that results will improve in 'quality, substance and robustness' if the public is involved (Hoff 2015). While the latter is closer to our purposes, what permeates both approaches to public involvement is the sense that citizen involvement is an optional, not vital component of project realisation. Contrarily, on Samsø, as mentioned, participation and collaboration were the end products. Public participation did not improve the REI project; it made it.

\section{Everyone is a participant}

In this article I wish to show how the REI project became a reality, and this, in my view, is best done by focusing on the specific forms of participation through which the island community brought this new reality into being. If participation cannot be reduced to acts of compliance, acceptance or support how, then, can participation be approached in the case of Samsø's energy transformation? The argument I would put forth is that the islanders' level of activity, the way they cared for the projects, the sheer amount of work that was put into the RE projects by 'lay islanders' are important activities that are not captured by notions of acceptance, enrolment, etc. However, I still find participation to be the adequate frame for my empirical observations. As noted by Kelty, participation in itself can be a valuable resource (Kelty 2012: 5). On Samsø, the islanders' willingness to join the RE projects, to get engaged and put in the work were what mattered most to the realisation of the projects. What we need in order to understand the case of Samsø is an approach to participation that allows for an appreciation of the island public's involvement not as 'communication' or 'consultation' (Rowe \& Frewer, 2000), not as a means to avoid public opposition (Barnett et al. 2012), but as a necessary precondition for the realisation and success of the REI project.

As Walker et al. note, the participation literature has tended to focus on participatory measures and mechanisms, which has led to a centering on the formal moments of engagement which are "only part of the picture of how 'the public' [...] factors into processes of sociotechnical change" (2010: 931-32). I want to include into my notion of public participation informal practices; practices that are not stabilised as participation through the common apparatuses and sites of participation (elections, public meetings, consensus conferences etc.). But when participation becomes a less fixed and predefined phenomenon, how do we identify that which makes an act a characteristic 'act of participation'?

The type of participation encountered on Samsø resonates with what Noortje Marres and others have called 'material participation': "Rather than see 'participation' as an abstract political ideal, Marres investigates how it is enacted in everyday settings, how it is a practical achievement" (Hawkins 2014: 4). In her article "The Costs of Public Involvement" Marres develops her perspective on public participation in contrast to liberal theories of citizenship. As she puts it, "material participation comes to challenge an assumption

that has long been current in wider research and theories regarding public participation: the notion that participation can in principle be contained in a singular space of political or moral engagement (i.e. a public debate forum)" (2011: 514). Understanding participation as a material accomplishment, then, "invites an interrogation of the means by which participation is accomplished", just as it involves "a sense of public engagement as an embodied activity, taking place in particular locations and involving the use of specific objects and technologies" (Marres 2011: 511; see also Marres 2012).

This move from 'public' to 'material' participation implies the shifting of registers from the normative or evaluative tendencies of the participation literature reviewed above to the practical and empirical investigation of participation as it takes place on the ground. A 'material participation' perspective, furthermore, shifts focus from deliberation to practice and from formal arenas of political engagement to the everyday. Participation at this level, according to Marres, "may [...] enable participation in a politics of redistribution that goes well beyond the household" (527, my emphasis), but whether practices of material participation will impinge on a wider setting of formal politics is essentially an empirical question and not the most important one to answer in a situated analysis of processes of material participation. Samsø's REI project, at its very essence, connects the island to a transnational network of 'Renewable Energy Islands' as well as to a national political context, as I will touch upon in the following section, but this wider network in which Samsø is embedded is not the focus of this article.

Departing slightly from Marres' 'device-centred approach' (2011), my analysis focuses less on energy technologies' (such as smart electricity meters and green electric kettles) ability to 'materialize' public participation in environmental issues. While maintaining Marres' interest in the concrete, local practices of energy engagement, I focus on how the materialization of energy (the transformation of natural resources into energy) through collaborative achievements (district heating stations, windmills and solar systems) brings the Renewable Energy Island into being. The islanders' engagement with renewable energy, in Callon \& Rabeharisoa's words, "enabled [the islanders] to change their ontological status" (2008: 231). By being "heavily engaged" in "the production of entities [...] that participate in shaping their identities" (232), Samsø's status changes from that of a peripheral society under constant threat of 


\section{N}

NORDIC JOURNAL

of Science and Technology Studies

closure to a hopeful and self-assured society known world-wide as Denmark's Renewable Energy Island. The processes that led to this change are of a more 'social' character than the ones described by Marres, as cooperation and the strengthening of the community were essential to the REI project.

This approach which, directly or indirectly, takes energy as its starting point, is in line with Gabrys, according to whom "there may be more ways to materialize energy that are less directed toward instrumental objects of management, and more attentive to inventing new arrangements of practices and political possibilities" (2014: 2101). The materialities of energy "may articulate [...] the possibility for togetherness and attachment" (2100). This opening up of our expectations and investigations of what the materialisation of energy in RE projects can do will allow us to appreciate the diverse ways in which Samsø's RE projects came together as closely connected to our notion of material participation. Furthermore, when we apply this logic to community-based energy transitions, we notice how the social, economic, political and technological dimensions involved in the project blend. They cannot be kept separate in practice, because energy transitions and sustainability projects leave few aspects of life untouched (see Marres 2011). This allows us to appreciate the REI project as a community-building project.

How do we identify moments of 'material participation'? How do we know that we are "identifying instances of participation in the wild" (Fish et al. 2011: 14)? The costs of taking participation out of the confined space of the consensus conference or the open space meeting and into everyday life is that it becomes a distributed phenomenon. Material participation is variable, it cannot be fixated into specific forms but must be analysed in the particular setting in which it unfolds and followed as it moves from one setting to the next. One way of pinning down what 'counts' as acts of participation, I will argue, is to focus on how the REl actors themselves stage specific acts and events as instances of participation, thus making these events count as, exactly, public participation: participation made public. This makes participation first and foremost an empirical phenomenon, the definition of which is left to the implicated actors, the participants themselves.

\section{Authoring participation}

Marres defines participation as a performance or a demonstration. According to her, inherent in material participation is an element of publicity (2011: 516). When bringing material objects into the study of public participation, the materiality involved in acts of participation - objects, technologies, settings which facilitate or emerge from participation - become the visible traces of participation in practice.

At its heart, the REI project is a demonstration project and as such embedded in a wider national and international political setting. The project was devised by the Danish Ministry of Energy to showcase Danish technologies and demonstrate Danish leadership in climate and energy innovations (Energistyrelsen 1997). Public participation also played a role in the Ministry's project description and in the nomination of Samsø among four other islands. The Ministry's press release reads, "We chose Samsø because they submitted a convincing project proposal which is supported by all relevant interest groups on the island". The Ministry furthermore states that to secure support for the island's technological development, "the demonstration of innovative organisational, financial and ownership forms is a central element of the project" (Bünger 1997, my emphasis). The REI project was never just about implementing RE technologies; the original purpose was also to demonstrate the 'doability', the realism of such community-wide energy transformations.

In the STS literature, demonstrations are understood as political acts (see e.g. Shapin and Schaffer 1989, Rosental 2013, Barry 2001, Marres 2013). Following Barry, demonstration "whether it is understood in a technical or a political sense, is, or can be made to

be, a political matter. On the one hand, because there is a politics of who can, and who should be allowed and trusted to witness a demonstration [...] On the other hand, public demonstration is political, because the telling of a truth in public can never be described as disinterested - it is always intended to have effects on, or challenge the minds, or affect the conduct of others" (1999: 76-77). By taking on the status and role of demonstration project, Samsø became a political actor concerned with assembling a public around its example. What the Sams $\varnothing$ actors seek to demonstrate is new knowledge about the space of possibilities for local communities facing environmental change and socioeconomic challenges.

The REI project was originally conceived as a project in which public participation would play a central part in the demonstraton. But the specific form this participation would take was left up to the island's project developers. In the following sections I will go into more depth with this empirical question, but for now I will draw attention to the activities undertaken by the Energy Academy staff to communicate and demonstrate the role of the participatory processes in the REI project. The argument is that these framing operations - powerpoint presentations, tours around the island to visit windmills and district heating plants, etc. - participate in articulating certain activities as public participation, making these activities part of Samsø's message to the world.

For many of Samsø Energy Academy's five thousand annual visitors, the RE technologies are not the main attraction. The Academy's daily manager: "Our visitors don't come to see the world's newest, fanciest plant. Our offshore wind farm may have been among the largest in the world when we built it, but today it's probably the 
smallest. That's not how we sell tickets. Instead, it's about 'How on earth did we get people to accept it?' It's about the [social] processes, not the technologies" (field notes, September 2013). According to the manager, the RE technologies are the products of successful 'social processes'; they are the material results of participation. Following the logic of material participation, the RE technologies become "material devices of engagement [...] help[ing] to enact a particular form of environmental participation" (Marres 2011: 517). This form is one that highlights accept (the absence of opposition is vital when it comes to implementing landscape-changing technologies), cooperation (as we shall see, Samsø's workers had to handle the practical tasks in collaboration), coordination (project developers and citizens' groups worked hard to secure necessary signatures, licenses etc.), and, simply, hard, time-consuming project work. The RE technologies stand proudly in fields and villages as public enactments of material participation, and this is what is highlighted in the Academy's arranged tours around Samsø: how the community came together to build the RE Island. The demonstration of participation in this way becomes internal to the practices of material participation on Samsø. Demonstration, publicity, practice and participation cannot be separated; they all become part of the 'truth' demonstrated on Samsø and shared with a global audience.

When Academy employees in their presentations at the Energy Academy show a photo of a farmer and windmill owner sitting at the top of his windmill overlooking Samsø (see photo below); when visitors at the district heating plant in Ballen-Brundby are invited to take pictures of the calendar with each date carrying the same name, Arne, signifying that Arne is day in, day out doing his job of making sure the plant is functioning (see photo page 23. and see p. 25 for a photo of tourists photographing the plant); and when ten-year-old summaries of meetings in e.g. 'the woodchip and fuel pellet working group' are found in the attic of the Energy Academy, carefully scanned in and uploaded to the Academy's digital archive of the REI project, www.energiinstituttet.dk ('the energy institute'); then those activities of publicity frame these acts as acts of participation central to the realisation of the REI project. This type of participation, manifested in hard work and personal investments, is usually not as well-documented as more traditional types of public participation taking place in e.g. public meetings. In connection with the REI project a large number of citizens' meetings were convened inviting the islanders to share their visions for Samsø and discuss how the REI project might help realise these visions. These meetings are amply documented (see. e.g. Møller et al. 1999). But so are the mundane meetings of which there were hundreds; the budgets and applications for funds; even email correspondences have found their way into the digital REI archive as just as valuable, but less readily visible and less sensational, instances of participation on Sams $\varnothing^{5}$

The demonstrations are what make certain practices into 'practices of participation'. Understanding participation in this way means leaving up to the actors what counts as participation rather than relying on theory to identify which acts can be defined as such. Accordingly, the object of participation (science and technology, or community-building), the issues of participation (democratic legitimacy, knowledge, or cooperation) and the participants (experts, 'lay citizens', or simply citizens) become open empirical questions as the actors themselves become the authors of participation.

For the analysis I have selected examples which are both decisive moments on Samsø's trajectory toward becoming Denmark's Renewable Energy Island and instances of material participation taking place in various sites and assuming different faces. They are examples chosen to illustrate how, without the islanders' participation of the specific type which we call 'material', the REI project would not have been realized. The selected stories, furthermore, all relate to the building and maintenance of Samsø's district heating plants. To conclude the article I return to the discussion of the role and character of participation on Samsø.

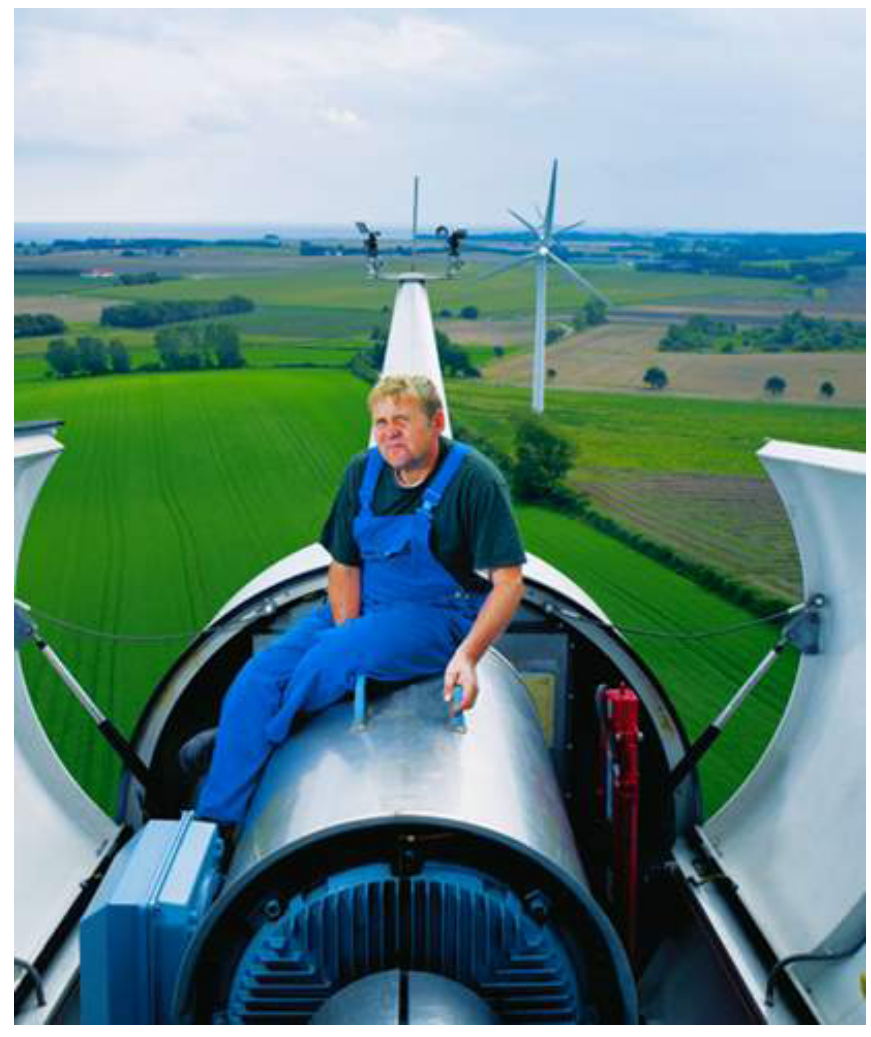

Farmer Jørgen Tranberg on his windmill. Photo: www.energiakademiet.dk

5 It should be noted, however, that while the digital archive has generously made various materials available, there was never any systematic collection of documents related to the REI project. 


\section{Acting through energy}

It was the REI project that brought climate change to Samsø. Hermansen, the director, describes how at the beginning of the REI project it came as quite a shock to the local project developers, himself included, that the opportunity to 'make the world a greener place' was not welcomed by the islanders as sufficient reason to join the project. "The citizens think differently", the director remembers, "their concern is, 'but what about my job?' So we started turning risk into possibility instead of focusing on climate risks. We started calculating how many jobs the project would generate" (Nov 2013).

Especially the farmers and workmen who became implicated in the project by virtue of their jobs - the farmers owners of the fields where the onshore mills would be placed and therefore prospective windmill (co-)owners, the workers' labour essential to the realisation of the projects - stress the importance of the business opportunities built into the project. "A poor bugger like me doesn't invest DDK twenty million [EUR three million] for the sake of idealism!", the farmer in the above photo who owns one land-based windmill and half an offshore wind turbine, remarks (interview, Nov 2013). From the landscape windows in his newly built house overlooking his fields he can follow the movements of his windmill. A windy day means money in the bank for him, he tells me ${ }^{6}$.

When the islanders talk about the survival of the island community, they talk about preserving their jobs, their livelihoods and homes. Renewable energy did not become a shared concern for the community until it became the means through which life as the islanders knew it could be sustained. Thus described, the REI project might evoke the familiar STS concept of 'the boundary object'. The project became a shared reference point "plastic enough to adapt to local needs [...] yet robust enough to maintain a common identity across sites", allowing heterogenous groups inhabiting 'different social worlds' to work together toward a common goal while following their own interests (Star and Griesemer 1989: 393). The REI project is certainly an example of how keeping an object vague and open to multiple meanings may help rather than hinder its ability to gain support among various stakeholders. Yet, in the empirical context of Samsø the concept of the boundary object misses the mark slightly.

On Samsø, it is problematic to speak of different social worlds, since, as noted above, the islanders share the general understanding that they are 'all in the same boat'. "Gathered around a campfire", as the director Hermansen expresses it, the islanders share a common understanding of the main challenges of island life. Every businessman, worker or farmer has a set of professional interests and a set of civic interests which he or she shares with

6 Several news articles have been written about the Sams $\varnothing$ wind farmers and their business-oriented approach to their RE investments. One heading, translated from Norwegian, reads, "Here the farmer makes money on wind power" (Hirth, 2015). the other islanders. While the islanders may have different smallscale politics, they all share a concern for the future and viability of the island. Getting the islanders to support and cooperate on the REI project was not first and foremost a question of designing a project vague enough to accommodate heterogeneous interests; the challenge was to construct the REI project as the solution to Samsø's problems. With Gabrys and Marres' understanding of participation as material, we can appreciate how exactly an energy project could become just that: a common solution supported by a diverse but united group of islanders.

A notion akin to but more fitting than the boundary object and closely related to energy is that which Gabrys calls 'the diverging materialities of energy' (2014): acting through energy allows for translations between various registers. Energy transitions can be framed in economic terms, as being about securing a sustainable flow of income and jobs. They can be about the environment and/ or about how climate change demands that we shift our energy sources, habits and modes of production. They can be linked to moral, social and political issues. These diverse registers do not exclude one another but co-exist and impinge on each other, and the resulting muddying of the picture of what 'participation' looks like in practice is exactly what makes this type of participation material. Moreover, this removes us further from the boundary object the different meanings of which might intersect but are

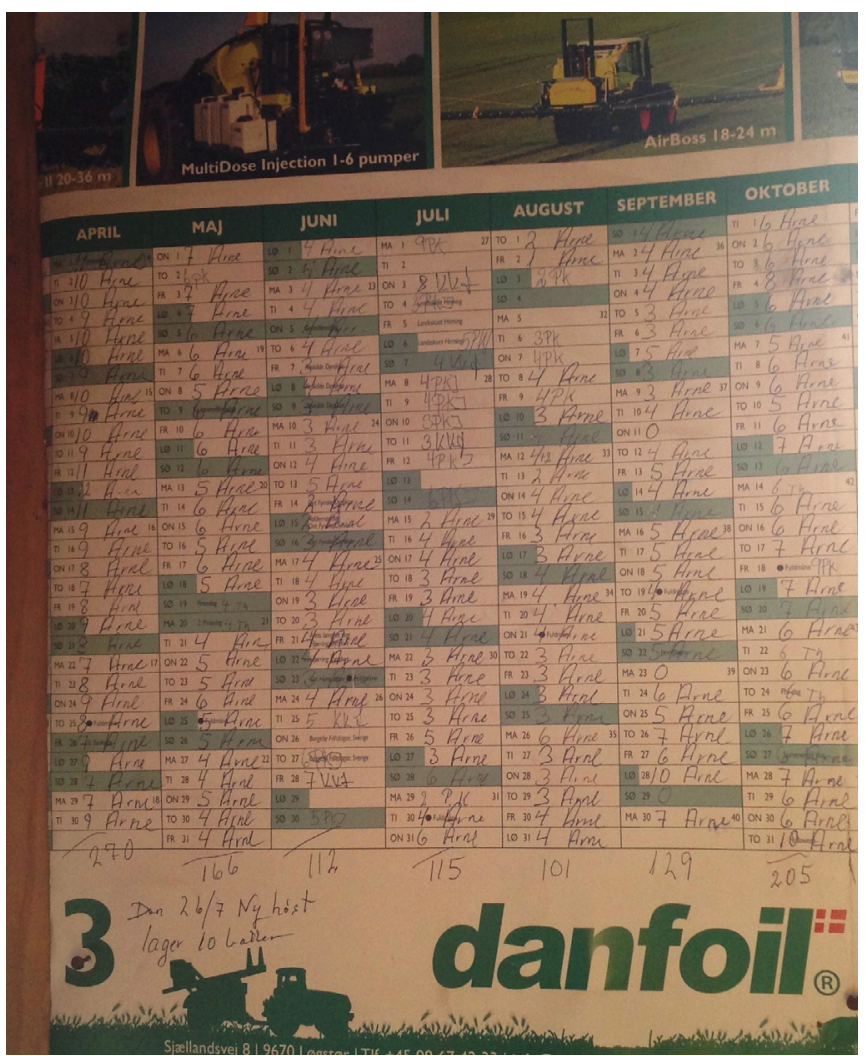

Arne's maintenance schedule. Photo: Irina Papazu. 


\section{N}

NORDIC JOURNAL

of Science and Technology Studies

essentially conceived of as separate (Star and Griesemer 1989: 390). While the farmer in the above quote coolly and impersonally emphasises the financial gains from his wind investments, later in the interview he describes the personal costs of being a central participant in a large RE project. The farmer chaired the local association building Samsø's offshore windfarm, completed in 2002. More than a decade later, he still vividly remembers the planning period: "If it was financially risky building the offshore mills? You bet it was! I had red wine running in my veins, I suffered from stress, I couldn't remember names - it was horrific!" While it is easy to brush off the wind-investing farmers' engagement as simple self-interest, they took risks and placed themselves in demanding roles serving not only their own narrow interests but the island community as a whole.

Further, during the course of our interview the farmer also mentioned $\mathrm{CO}_{2}$ and climate change without me prompting him, and his

\section{Making district heating plants}

The analysis is centrered upon instances of material participation relating to the development and maintenance of Samsø's district heating stations and will illuminate how, without the collective effort of the islanders, district heating would not have become part of Samsø's low-carbon reality. I limit the analysis to the district heating projects for reasons of space, but also because other large projects under the REI umbrella such as the on- and offshore wind turbines were to a lesser extent a collective undertaking. Twentyone wind turbines were erected in the span of the REI project, and while all are locally owned, only three are owned by co-operatives of islanders. The majority of the mills are owned by farmers and five offshore windmills are financed by Samsø Municipality. Building wind turbines is, furthermore, a more specialised endeavour than organising district heating plants and therefore involves 'lay citizens' to a lesser degree. I focus on the establishment of the district heating plants because they offer more fruitful instances of material participation in practice.

Sixty percent of Samsø homes are heated by one of the four district heating stations on the island. Of the remaining forty percent not within the range of the plants - district heating is very local due to heat loss from the underground pipes - twenty-five percent have invested in individual renewable heating systems, and many households have replaced their oil-fired burners with more eco-friendly alternatives following campaigns in the local newspaper. District heating is a common energy technology in Denmark, and prior to the REI project Samsø already had one district heating station in place in the biggest village Tranebjerg. The plant was established in 1993 and is straw-based like three in four of the island's heating stations. The straw is provided by local farmers on a contractual basis. The burning of straw heats up water, which is directed to the customers' houses through underground pipes. The ashes are returned to the farmers' fields for fertilization. It is cheaper than wife told me about his interest in acquiring an electric car. Unable to keep the registers apart, participating in an energy project activates and connects various considerations, interests and sites the home, the farm, the wind turbine cooperative; this is the core of material participation. Through this perspective, then, we can analyse and appreciate energy transitions as involving processes of inter- or co-articulation (on this concept see Marres 2011, Callon 2009, Cochoy 2007) connecting the environmental, the economic, the social and the political, the home and the public domain. While we might find it provoking that a major wind energy investor is apparently primarily 'doing it for the money', we should resist the urge to see these registers as antithetical. Instead, they work in tandem, supporting each other. The inclusiveness of the REI project opened up the project to a broad range of actors, including the businessmen without whose participation (through financial investments and membership of the associations organizing the activities) the project goals could never have been realised.

gas-, oil- or electricity-based heating, and the process is wastefree and produces a minimum of $\mathrm{CO}_{2}$ (Ramboll).

The islanders' and especially the workers' previous experiences with the technology played a role in paving the way for the district heating stations in the REI project, but it is one of experience rather than expertise. The chairman of Samsø's business council and owner of a plumbing and heating business engaged in the island's reorganization here tells a typical Samsø story about how the original Tranebjerg plant came into being and what the process meant for the later REI project:

[Renewable energy on Samsø] actually started really big. In 1991 in Tranebjerg a citizen group took the initiative to build a straw-fired district heating station in order to lower their heating bills. A postman took the initiative, and the local working group did a good job. Tranebjerg was a good spot for it, too [most of Samsø's central institutions are based in Tranebjerg]. The group contacted the utilities company ARKE and asked if they were interested in running a local heating plant. ARKE became the building owner and we were left to carry out the task, which we as local workmen were conscious to gain from as much as possible. Since none of us could cope with the full task alone, we had to stand together. We created a construction which allowed local blacksmiths and contractors to work together. That's how we learned the value of cooperation, and that's how we managed to keep all the jobs on the island - even in the middle of a recession. That was the first time we collaborated on a large scale like that and got a good thing out of it. The heating station proved its worth, so when the masterplan for the REl project was disclosed, neither workmen nor consumers were reluctant to support the plans for the new plants. (interview, May 2014) 
This is a carefully crafted account of the events. As chairman of the business council and one of those islanders you encounter at all kinds of events around the island, the plumber has refined his story and tailored it to fit a narrative of collaboration between local enterprises, adding his own twist stressing the importance of keeping local jobs on the island. Again, it is the social and economic features of the project that are highlighted along with the prospect of lowering heating bills, while the environmental benefits of biomass-based heating go unmentioned. The chairman's story is crafted to demonstrate how new practices of collaboration between Samsø's workers grew out of necessity, underlining the islanders' flexibility and ability to handle change.

The account also communicates the sense that if no one takes the initiative and gathers a group, nothing will happen, but that the initiative is open to all, even the postman. Again, expertise means little. This sense of initiative combined with fragility permeates the

\section{Forming working groups}

In the course of the REI project, a citizens' group formed around the idea of building a district heating plant in the northern part of the island, an area typically exempted from RE technologies because of its scenic beauty and preserved nature. As part of the REI project a masterplan was developed laying out in some detail which RE technologies were to be built where (Samsø Energiselskab et al. 1997), but the initiative to embark on the projects often lay with groups of islanders not involved in the development. If no such group existed in an area, there would be no one to take care of the practical work involved in the project. The then mayor of Samsø remembers: "They showed up from Nordby asking: 'What's our position in the line? We also want a heating station!' So we got the island: everything you see, from the closed slaughterhouse to the functioning sports centre, has a story and everyone knows who built it. Ethnographer Laura Watts captures a similar experience in her descriptions of her fieldwork in the Orkney Islands, which have been similarly singled out for their work in meeting the challenge of climate change: "The fragility of Orkney is an everyday experience for the people who live there. The dependent infrastructures of contemporary living, forgotten and literally buried in urban places, are visible and embodied in the weather-reliant ferries, in the occasional electricity blackouts, in the 'not spots' of absent broadband and mobile phone signal: insistent infrastructure..." (Watts 2014: 30). Everyone is a participant, because if you do not invest your life, your labour, your time and resources to make island life function, it might break down. The REI project was an opportunity to build something together, to continue this tradition, and as such it was not a new departure, although the scale and the framing of the project - energy self-sufficiency, carbon-neutrality - were new to Samsø.

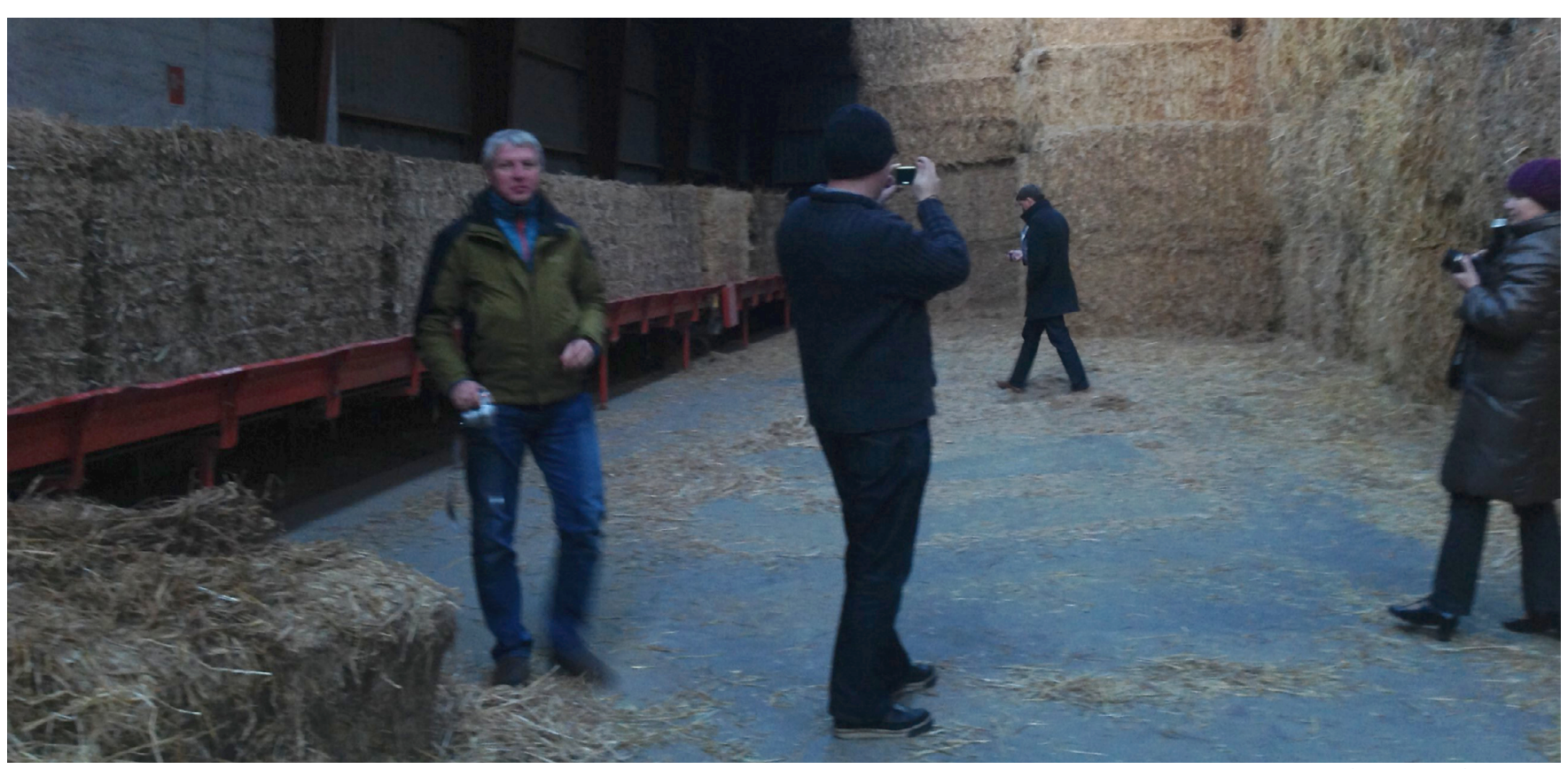

group going, and we ended up with a plant fuelled by woodchips from the local forest and solar collectors [a necessity because of the many tourists wanting to heat their houses during summer], the only one of its kind as far as I know. That kind of group never existed in Besser [another village], so they never got a district heating plant" (interview, Nov 2013). The realisation of the different parts of the REI project thus depended on the willingness of the inhabitants of the relevant areas to take the initiative and put in the work. According to the chairwoman of the Nordby working group, the group consisted of ten people "representing all relevant interests": there was a representative of the village church, one from the school, a blacksmith and one of the area's big farmers, as

Renewable energy tourists. Photo: Irina Papazu. 


\section{$\mathbb{N}$}

NORDIC JOURNAL

of Science and Technology Studies

well as someone from ARKE, the utility company which ended up the main investor in the project (two of the four district heating plants are owned by ARKE, now NRGi, while the remaining two are local cooperative associations). Creating support for the project and recruiting customers for the plant involved a lot of coordination work on the part of the working group, including distributing letters door-to-door to all households, public meetings and house calls. "There was an incredible drive and faith in the project!" the chairwoman remembers (interview, Nov 2013).

Although it only took a working group of ten people to get the projects off the ground, the district heating plants needed the support of seventy percent of the population within the plants' reach to be viable. If less than seventy percent signed up as customers of a plant (usually ranging from 50 to 200 households), the project would be dropped. This never happened, but it took a lot of work to turn the majority of the relevant villages' populations into customers of the plants. Information meetings were held and letters distributed door-to-door carrying the message that if the household signed up as a member from the beginning, the price would be only DDK one hundred (EUR thirteen). If the household waited a few months, the price of connection would go up to DDK one thousand (EUR one hundred and thirty), and if the household did not sign up until after the heating pipes had been dug in, it would be considerably more expensive. This price-focused strategy was combined with distributed folders urging the villagers to 'do the green deed of the day', adding an element of environmental concern to the campaign (Svendsen 1999).

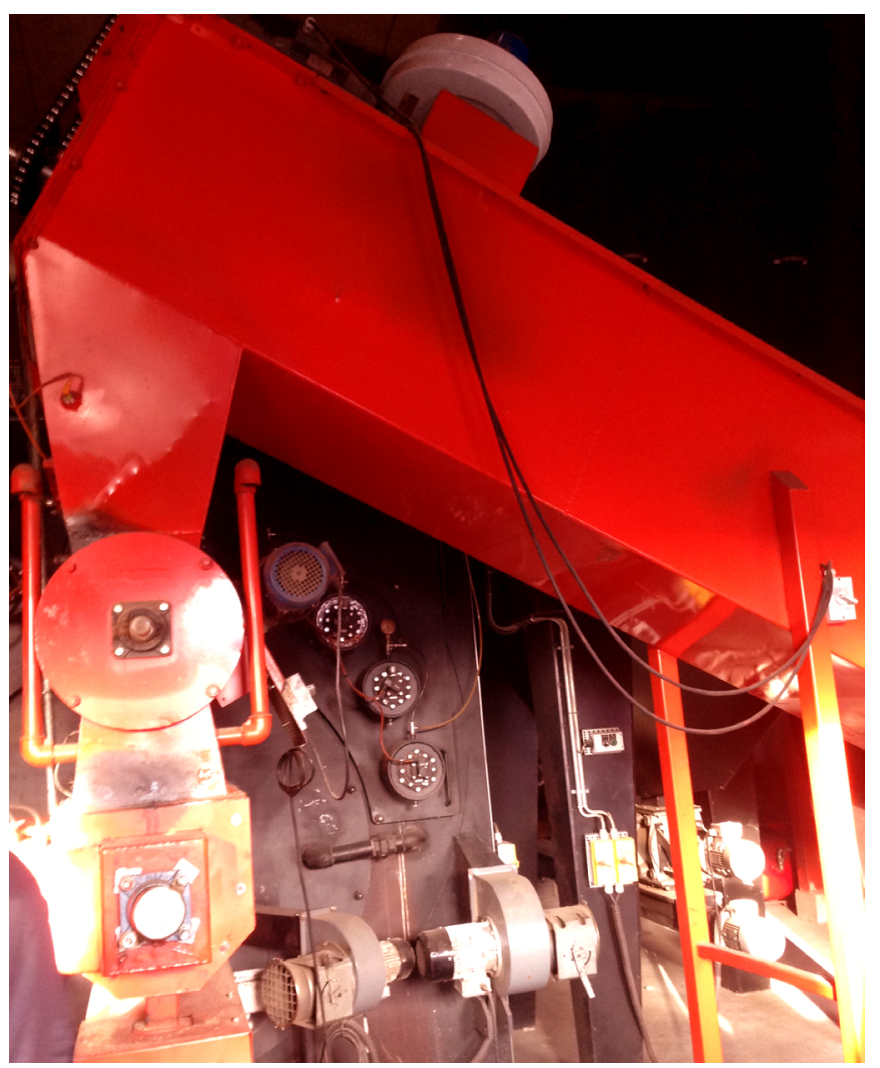

District heating plant equipment. Photo: Irina Papazu.
A lot of practical work was involved for the working group volunteers in going from door to door, following up on the letters and enrolment contracts that had been distributed by mail. The minutes from a working group meeting offer a glimpse into this work. Eight members of the local working group and five representatives of the energy company were present. The locals provided the space for the meeting at the local continuation school as well as the coffee; the representatives from the energy company brought the bread, the minutes duly note. The meeting, held in the late afternoon, would, in accordance with Danish tradition, involve plenty of coffee and an afternoon snack. The rest of the document consists of a table listing the village households which had yet to sign up, and the actions to be taken by the working group members in each case. The table, meticulously managing all prospective customers, reads: "Address 1: Has been contacted numerous times. Awaiting reply. Address 2: Haven't received their contract. XX investigates this. Address 3: The contract is on its way, the owner currently abroad... The house is for sale... New owner... Will be contacted by XX...", and so on (Jepsen, 2000).

The process of getting seventy percent of the households in the area to register as customers of the plant involves meticulous, mundane work on the part of the working group members trying their best to keep track of and contact everyone who has yet to sign up individually. But turning customers into participants also requires some work and effort. Changing your home's heat source takes some level of engagement. The homes, especially those which were heated by oil-fired burners, experienced not insignificant changes due to the transition: burners were removed by workers, pipes were dug, gardens turned into construction sites for a while. Everyday life was, if briefly, affected. If the villagers had not accepted this disturbance, the project would have come to nothing. I count this as an instance of material participation as this is participation as a resource and necessity, and it involves a measure of concrete work. Although the intensity of this participation is lower than that involved in being a member of a working group, it is still concrete, it is practical, and it takes consideration.

\section{Reorienting duties and livelihoods}

Once a district heating plant has been established, it does not need a lot of looking after, or significant repairs, but some everyday maintenance is needed. I visited the cooperatively owned strawfired plant in Ballen-Brundby and spoke to the elderly farmer responsible for the daily maintenance. He shows up every morning around seven, and in the winter in the afternoon as well, to make sure that all machines are running. There have been no major failures in the plant's thirteen years' lifetime, but while I was there for the interview the local electrician showed up to make a minor repair. The farmer tidies up, sweeps the floors and places five to seven bales of straw on the conveyer belt (more in winter). Every day after fulfilling his tasks, as noted above, he signs his name on the wall calendar in the large hall (see photo below). He - together 


\section{N}

NORDIC JOURNAL

of Science and Technology Studies

with the two cats living in the straw bales that keep down the mice population - keeps the plant going. Without his daily work there would be no functioning plant. I ask him how he feels about the role he continues to play in the REI project. His reply: he is happy about it because the plant functions; because straw-based heating is fifty percent cheaper than oil, "so we can keep the money on the island instead of sending it down to the Arabs"; and because it sustains workplaces through administration, minor repairs etc. (interview, May 2014). The motivations for being part of the REI project are diverse, and this farmer is known for his aversion against 'Arabic oil'. But Arne was not the only islander whose workday and skills were redefined through his participation in the REI project.

One final aspect which I will describe as material participation is the way in which the REI project necessitated the reorganization of the professionals' livelihoods. The farmers were urged to sell their straw instead of letting it rot on the fields to manure the soil as was customary. The plumbers who specialized in operating the islanders' many oil-fired burners were asked to accept the gradual phase-out of this technology, the foundation of their business, and had to go through further training to acquire the skills involved in the operation of the RE technologies introduced by the REI project.

The island electrician had to attend courses to learn how to make minor repairs on the windmills and district heating plants. He remembers, "We [the workmen] felt like the REI project was an incredibly comprehensive undertaking, and many were sceptical at first. The plumbers' core business, for example, had to be completely transformed. But as things began to take shape it snowballed as we understood that it was actually good business." (interview, May 2014). According to the blacksmith who was president of Samsø's business council at the time and the first to introduce the Ministry's REI project proposal to Samsø, the project has created "an incredible amount of work for the island's workers, it's been

\section{Conclusion}

Social science research on public participation tends to want to 'decide', to define independent of empirical analysis, what counts as participation. This turns public participation into a phenomenon that takes place in arenas specifically designed for the purpose, where the public is involved in order to secure acceptance and support, to gain knowledge about lay people's perspectives, or to strengthen the democratic legitimacy of an endeavour. While the reasons for involving the public vary, the power to decide what counts as participation stays with the theorists. I have attempted to show the actors on Denmark's Renewable Energy Island as authors of participation. Samsø did not join the REI project to experiment with $\mathrm{CO}_{2}$ neutrality. Samsø's energy transition was first and foremost about creating jobs, about building something together. It was about strengthening faith in Samsø as a viable community.

This focus on the community made the REI project valuable to bloody great for all the workmen. My attitude was that everything that could be done locally had to be done locally. My honourable job was to create employment, as simple as that." (interview, May 2014). Once again, green ambitions did not make the blacksmith sign Samsø up to be a Renewable Energy Island. He simply viewed the project as an opportunity to keep and create jobs on the island.

To sum up, when we understand participation as 'material', we distance ourselves from an understanding of participation as a neatly delineated but also limited phenomenon, identified in bounded spaces unpolluted by the concerns of the everyday. Samsø's energy transition involved people and their lives on a more dispersed scale: islanders with different backgrounds and motivations joined to work toward what became the common goal of creating a Renewable Energy Island. Some had to reorientate their livelihoods, others experienced changes to their homes, and people spent a lot of time and energy on their involvement, but the various motives, meanings and dimensions attached to the RE projects never seemed to produce fundamental conflict or exclude one another. Rather, the flexibility of the REI project, the way it managed to satisfy and accommodate a great array of interests, proved to be its strength. This flexibility can be thought of as connected with the diverging materialities of energy (Gabrys 2014 , Marres 2011): the versatility that comes with climate and energy initiatives as activities that leave few aspects of life untouched and possess the ability to activate and co-articulate registers of life that tend to be understood as alien to 'purer' accounts of public participation.

The material participation perspective, to conclude, allows us to appreciate and analyse certain acts - acts central to Samsø's political performance as a demonstration island - as expressions of participation which would be marginalized in analyses employing more traditional perspectives on what counts as 'participation'.

the islanders. The islanders were not asked to 'accept' the new RE technologies; they were not 'informed' about the projects; they were invited into the heart of the processes, because without their involvement there would have been no projects. The participation of the public became a resource in itself. Therefore, I shifted the vocabulary slightly, defining the processes of participation on Samsø not as 'public', at least not in the conventional sense, but as 'material', drawing attention to the ways in which this participation played out in everyday settings, paying attention, with Gabrys (2014), to how the materialization of energy into RE technologies helped articulate new ways of being for the island community. Villagers formed working groups bringing together different interests. Workers learned to cooperate and they acquired new skills, because this was what the projects demanded. Farmers took risks, invested, reorganized their businesses, set up new business plans, made room for windmills on their fields and started selling straw to the heating plants. 
Marres (2011, 2012) defines participation as a performance or demonstration as well as a practical act. This element of publicity inherent in material participation has informed our understanding of what 'counts' as participation. When, during my fieldwork, I contacted village representatives or farmers, asking for interviews about the roles they played in the REI project, their consent alone showed me that they consider themselves participants in the project. The interviews attest to their positions as actors in the REI project. This goes for Samsø Energy Academy's presentations and tours as well. While the windmills from the nineties the visitors are taken to see may once have been impressive technological achievements, today they are manifestations of a cooperating community. These objects, technologies and settings - including 15-year old minutes from meetings - become the visible traces of participation in practice, when we are not there to witness it ourselves.

The focus on strengthening the viability of the local community is a frame not often associated with green energy transitions, where

\section{Literature}

Antonsen, M., K. Ask and H. Karlstrøm. 2014. The Many Faces of Engagement. Nordic Journal of Science and Technology Studies 2(2): 3-4.

Barnett, J., K. Burningham, G. Walker and N. Cass. 2012. Imagined Publics and Engagement Around Renewable Energy Technologies in the UK. Public Understanding of Science 21(1): 26-50.

Barry, A. 2001. Political Machines: Governing a Technological Society. The Athlone Press.

Blok, A. 2007. Experts on Public Trial: On Democratizing Expertise Through a Danish Consensus Conference. Public Understanding of Science 16: 163-182.

Bonne, N. Samso: The Danish Island Living Off-Grid. The Guardian, September 21 2008. Accessed August 102015

Bruun Jensen, C. 2005. Citizen Projects and Consensus-Building at the Danish Board of Technology: On Experiments in Democracy. Acta Sociologica 48(3): 221-235.

Bünger, J. 1997. Pressemeddelelse: Samsø bliver Danmarks Vedvarende Enerai- $\varnothing$. The Danish Ministry of Environment and Energy. Accessed August 62015

Callon, M. 2009. Civilizing Markets: Carbon Trading Between In Vitro and In Vivo Experiments. Accounting, Organizations and Society 34: 535-548.

Callon, M. and V. Rabeharisoa. 2008. The Growing Engagement of Emergent Concerned Groups in Political and Economic Life: technological achievements and technical innovation tend to be in focus. This article has attempted to describe a local energy transition as a practical challenge involving the entire community, bringing with it a revitalization of that community and new hopes for the future. Through the project developers' focus on publicity and demonstration, the island has furthermore entered into a global network in which Samsø has become one of the prime examples inspiring other would-be renewable energy communities, be they islands, cities or countries.

This shift to a more hopeful or visionary frame for thinking about green energy transitions is a central contribution of this article: providing a sociological framework building on theories of material participation through which we can appreciate in positive terms the ways in which large-scale RE projects need not foster public opposition but may instead bring new life to a community on the many registers that are activated by the project: economic, social, environmental, political.

Lessons from the French Association of Neuromuscular Disease Patients. Science, Technology \& Human Values 33(2): 230-261.

Callon, M. 1986. Some Elements of a Sociology of Translation: Domestication of the Scallops and the Fishermen of St. Brieuc Bay. In Law, J. (ed.) Power, Action and Belief: A New Sociology of Knowledge?, 196-223. Routledge.

Cammaerts, B. and N. Carpentier. 2005. The Unbearable Lightness of Full Participation in a Global Context: WSIS and Civil Society Participation. In Servaes, J. and N. Carpentier (eds.) Towards a Sustainable Information Society, 17-49. Intellect.

Cardwell, D. Green-Energy Inspiration off the Coast of Denmark. New York Times, January 17 2015. Accessed August 152015.

Cochoy, F. 2007. A Brief Theory of the 'Captation' of the Public Understanding the Market with Little Red Riding Hood. Theory, Culture \& Society 24: 213-33

Dunbar-Hester, C. 2014. Producing 'Participation'? The Pleasures and Perils of Technical Engagement in Radio Activism. Public Culture 26(1): 25-50.

Energistyrelsen. 1997. Notat. Energistyrelsens vurdering af projektforslag: Vedvarende energi- $\varnothing$. October 16 1997, the Danish Ministry of Environment and Energy.

Epstein, S. 1995. The construction of lay expertise: AIDS activism and the forging of credibility in the reform of clinical trials. Science, Technology \& Human Values 20(4): 408-437. 
Felt, $U$ and M. Fochler. 2009. The Bottom-Up Meanings of the Concept of Public Participation in Science and Technology. Science and Public Policy 35(7): 489-499.

Fish, A., L. Murillo, L. Nguyen, A. Panofsky and C. Kelty. 2011. Birds of the Internet: A Field Guide to Understanding Action, Organization and the Governance of Participation. Journal of Cultural Economy 4(2): 157-187.

Gabrys, J. 2014. A Cosmpolitics of Energy: Diverging Materialities and Hesitating Practices. Environment and Planning A 46: 2095-2109.

Hardin, G. 1968. The Tragedy of the Commons. Science 162 (3859): 1243-1248.

Hawkins, G. 2014. Review: Noortje Marres: 'Material Participation - Technology, the Environment and Everyday Publics' \& Andrew Barry: 'Material Politics - Disputes Along the Pipeline'. Contemporary Political Theory 2014.

Hermansen, S., Aa. Johnsen, S. P. Nielsen, J. Jantzen, M. Lundén and P. J. Jørgensen. 2007. Samsø, a Renewable Energy Island: 10 Years of Development and Evaluation (10 Year Report). Samsø Energy Academy. Accessed August 102015.

Hirth, M. L. 2015. Her tiener bonden penger på å lage vindkraft. Fornybar Energi, August 5 2015. Accessed August 102015.

Hoff, J. 2015. 'Think Locally, Act Locally': Climate Change Mitigation and Citizen Participation. In Hoff, J. and Q. Gausset (eds.) Community Governance and Citizen-Driven Initiatives in Climate Change Mitigation. Routledge/Earthscan: London \& New York.

Irwin, A., T. E. Jensen and K. E. Jones. 2013. The Good, the Bad and the Perfect: Criticizing Engagement Practice. Social Studies of Science 43: 118-135.

Jepsen, E.T. 2000. Mødereferat samt klage over afgørelse vedr. VVM-pligt for Varmeværk, Nordby. Samsø. Lokalvarme i Nordbv og Mårup. møde 5.23. november 2000. Accessed August 102015.

Karnøe, P. 2013. Large Scale Wind Power Penetration in Denmark: Breaking Up and Remixing Politics, Technologies and Markets. Revue de l'Energie 611: 12-22.

Kastens, B. and J. Newig. 2008. Will participation foster the successful implementation of the water framework directive? The case of agricultural groundwater protection in northwest Germany. Local Environment 13(1): 27-41.

Kelty, C. 2012. From Participation to Power. In A. Delwiche and J. Hendersen (eds.) The Participatory Cultures Handbook. Routledge.

Kingsley, P. Windfarms: Is Community Ownership the Way Ahead?
The Guardian, November 5 2012. Accessed August 102015.

Latour, B. 1993. We Have Never Been Modern. Harvard University Press.

Lawrence, A. 2006. 'No Personal Motive?' Volunteers, Biodiversity, and the False Dichotomies of Participation. Ethics, Place and Environment: A Journal of Philosophy and Geography 9(3): 279-298.

Marres, N. 2012. Material Participation. Technology, the Environment and Everyday Publics. Palgrave Macmillan.

Marres, N. 2011. The Costs of Public Involvement: Everyday Devices of Carbon Accounting and the Materialization of Participation. Economy and Society 40(4): 510-533.

Marres, N. 2013. Why Political Ontology Must Be Experimentalized: On Ecoshowhomes as Devices of Participation. Social Studies of Science $0(0)$ 1-27.

Møller, T. S. and S. O. Nielsen. 1999. Café GO ENERGI. Accessed August 62015

Ramboll. Towards CO2 Neutral Heating. Accessed August 62015.

Rosental, C. 2013. Toward a Sociology of Public Demonstration. Sociological Theory 2013 31: 343.

Rowe, G. and L. J. Frewer. 2000. Public Participation Methods: A Framework for Evaluation. Science, Technology and Human Values 25(1): 3-29.

Samsø Energiselskab, Samsø Erhvervsråd, Samsø Landboforening, Samsø Kommunalbestyrelse, ARKE and Planenergi. 1997. Tiårsplan: Første energiplan for Samsø. Samsø Energiselskab. Accessed August 102015.

Shapin, S and S. Schaffer. 1989. Leviathan and the Air-Pump: Hobbes, Boyle and the Experimental Life. Princeton University Press.

Star, S. L. and J. R. Griesemer. 1989. Institutional Ecology, 'Translations' and Boundary Objects: Amateurs and Professionals in Berkeley's Museum of Vertebrate Zoology, 1907-39. Social Studies of Science 19(3): 387-420.

Stirling, A. 2008. 'Opening Up' and 'Closing Down': Power, Participation and Pluralism in the Social Appraisal of Technology. Science, Technology and Human Values 33(2): 262-294.

Svendsen, P. 1999. Borgermøder vedr. Iokalvarme på Samsø, 22. og 24. juni 1229, Brundby Hotel og Nordby Kro, Samsø. Accessed August 102015.

Suryanarayanan, S. and D. L. Kleinman. 2013. Be(e)coming experts: 
The controversy over insecticides in the honey bee colony collapse disorder. Social Studies of Science 43: 215-240.

Sørensen, K. H. 1994. Technology in Use: Two Essays in the Domestication of Artefacts. STS Working Papers 2/94. Senter for Teknologi og Samfunn.

Tagliabue, J. Turbines and Straw, Danish Self-Sufficiency. New York Times, September 29 2009. Accessed August 102015.

Walker, G., N. Cass, K. Burningham and J. Barnett. 2010. Renewable Energy and Sociotechnical Change: Imagined Subjectivities of 'the Public' and Their Implications. Environment and Planning A 42: 931-947.
Walsh, B. Time Magazine, March 16 2009. Accessed August 102015.

Watts, L. 2014. Liminal Futures: Poem for Islands at the Edge. In Leach, J. and L. Wilson (eds.) Subversion, Conversion, Development: Cross-Cultural Knowledge Exchange and the Politics of Design. MIT Press.

Wynne, B. 1991. Knowledges in Context. Science, Technology and Human Values 16(1): 111-121.

Wynne, B. 1992. Misunderstood misunderstanding: Social identities and public uptake of science. Public understanding of science $1(3)$ : 281-304. 